\title{
TEACHERS' EXPERIENCE OF THE INTRODUCTION OF STUDENT-CENTERED PEDAGOGIES THAT PROMOTE LIFLONG LEARNING AND ENTHUSIASM FOR CHEMISTRY AND SCIENCE
}

\author{
Farrugia, J osette \\ Faculty of Education University of Malta, Malta
}

\begin{abstract}
This paper looks at the first steps taken by a group of Maltese teachers participating in the EU funded FP7 project aimed at promoting inquiry-based learning (IBL) in Mathematics and Science classrooms across Europe, PRIMAS, by providing long-term professional development (PD) to teachers during the introduction and implementation of IBL in an examination-oriented culture. Data were obtained through teachers' reflective journals and interviews. Difficulties encountered and ways of overcoming challenges are presented. The main difficulties encountered may be classified as systemic difficulties; barriers due to teachers' personal beliefs and attitudes; and student-related difficulties. Peer support, support of school authorities, and long-term continued PD are needed to help teachers move away from traditional teaching and implement IBL strategies.
\end{abstract}

\section{Introduction}

Modern curricula and programmes include various lists of desired '21 ${ }^{\text {st }}$ century skills' or 'Key competences' needed by future citizens such as reasoning, critical thinking, creativity and problem solving, deeper learning, collaboration and communication, and learning how to learn (Annetta, Cheng \& Holmes, 2010; Business Higher Education Forum, 2005; European Commission, 2007).

Traditional methods of teaching and learning are deemed inadequate for helping students acquire the desired skills. While efficient for transmitting large quantities of material to students in a short time, they tend to promote passive and superficial learning with low retention and are least effective in helping students to attain knowledge and understanding (Eggleston et al, 1976 and Wallace, 1996 cited in Osborne \& Collins, 2001). As Osborne and Collins (2001) put it, in these situations pupils are frequently "frog-marched across the scientific landscape, from one feature to another, with no time to ... absorb what it was that they had just learnt" (p. 450).

In addition, an increase in motivation and an increase in the number of students taking science-related careers are all highly desired results of science education. Recent reports (e.g. OECD, 2006) have shown an alarming decline in the number of students opting for University courses in science-related fields and this is attributed to their science education experience. The 2005 Eurobarometer study on 'Europeans, Science and Technology' reports a high level of dissatisfaction with the quality of science education in European schools. The majority of the respondents were of the opinion that "science classes at 
school are not sufficiently appealing" (p. 99). When reviewing literature related to student interest, Krapp and Prenzel (2011) identified pedagogy as a potential major influence on both situational and personal interest. Similarly Logan and Skamp (2013) observed a link between student interest in science and the pedagogical practices of science teachers in their four-year study of interest in science shown by a group of students. Other sources stress the importance of classroom practices that help in maintaining curiosity. For example OFSTED (2013) acknowledges that the best science teachers observed in the survey set out to maintain curiosity in their students.

On the other hand student-centred pedagogies that actively involve students are seen to be better suited for $21^{\text {st }}$ century aims and competences. One of these pedagogies is InquiryBased Learning (IBL) through which students can learn content knowledge, epistemic practices as well as soft skills such as collaboration (Hmelo-Silver, Duncan \& Chinn, 2007). However, a study reported in Maaß and Euler (2011) showed that the practice of IBL in European schools was rather limited: while applications and relation to daily life are frequent components of many science lessons, in chemistry the use of teacher-centred methods such as working out exercises appeared to be particularly frequent and the use of investigations appeared to be rare.

\section{Background}

\subsection{What is IBL?}

There are several interpretations of the terms inquiry and IBL but essentially student inquiry should "mirror what scientists do" (Martin-Hansen, 2002 p. 35). Two recent definitions of inquiry that have been influential to the current understanding of the pedagogy are those outlined by the National Research Council (NRC) (1996) and Linn, Davis and Bell (2004) respectively. The NRC (1996) defines inquiry as a:

multifaceted activity that involves making observations; posing questions; examining books and other sources of information to see what is already known; planning investigations; reviewing what is already known in light of experimental evidence; using tools to gather, analyse, and interpret data; proposing answers, explanations, and predictions; and communicating the results. Inquiry requires identification of assumptions, use of critical and logical thinking, and consideration of alternative explanations. (p. 23)

Linn et al. (2004) include other processes in the description of inquiry: "the intentional process of diagnosing problems, critiquing experiments, and distinguishing alternatives ... researching conjectures, searching for information, constructing models, debating with peers, and forming coherent arguments" (p. 4).

This definition also includes a way of how inquiry may be carried out by including 'debating with peers' in the definition. Many forms of inquiry in fact involve collaborative learning. 
Several reasons for using IBL have been identified: "as a result of collaborative inquiry learning, students acquire knowledge of how to do science as a common endeavour, they learn about the nature of science and the scientific content" (Bell, Urhahne, Schanze \& Ploetzner, 2010 p. 350). Similarly Bunterm et al. (2014) consider IBL to be: "characterised by activities that encourage the acquisition of both science content knowledge and process skills" (p.1939). Kirschner, Sweller and Clark (2006) find this to be problematic. They argue that IBL and other constructivist approaches are less effective and less efficient than direct instruction due to the resulting heavy cognitive load. However they assume that inquiry is always open, unguided and identical to open discovery learning. In response to this view, Hmelo-Silver et al. (2007) point out that many forms of inquiry and other constructivist approaches employ extensive scaffolding to help students reduce the cognitive load and support student learning. Cobern et al. (2010) found that students acquired comparable understanding of science subject matter irrespective of mode of instruction (direct vs inquiry) but the authors believe that inquiry has the additional benefits of generating greater interest, better retention as well as an exposure to scientific inquiry.

Other reports of research investigations show that IBL leads to better learning compared to teacher-centred instruction (e.g. Sesen \&Tarhan, 2011). Sesen and Tarhan (2011, p. 209) cite Adler (1982) who claims that "all genuine learning is active, not passive. It involves the use of the mind, not just the memory. It is the process of discovery in which the student is the main agent, not the teacher" (p. 209). Adler also describes the role of the teacher in this process: "as aids in the process of learning ... not as knowers who attempt to put the knowledge they have in their minds into the minds of their pupils" (p.209). This implies that a change in the way students learn and the quality of what they learn necessitates a change in what teachers do since: "we cannot expect students to change what they do if we are content for teachers to continue doing what they have always done" (Harwell, 2003 p. 2). In IBL the teacher occupies a less central role and actively involves students in the learning process. However teacher and student input in inquiry activities vary. The greater the student involvement, the higher the inquiry level. A number of authors present a continuum of inquiry levels or matrices to describe levels of inquiry and which components of the inquiry process would be enacted by the teacher and student respectively (Fradd, Lee, Sutman \& Saxton, 2001; Martin-Hansen, 2002; Olson \& Loucks-Horsley, 2000; Tafoya, Sunal \& Knecht, 1980). The levels of inquiry are described by terms such as open/full inquiry, guided inquiry, coupled inquiry, structured inquiry, and confirmation exercises. Chemistry and science content vary in type and students' inquiry skills develop with time. It is therefore necessary to use different kinds of inquiry according to the specific needs and contexts. It is equally important to increase the inquiry level of activities over time as students are likely to benefit more when engaged in such activities. Bunterm et al. (2014) observed that students who learnt topics through a guided-inquiry approach showed greater improvement in both 
science content knowledge and science process skills compared to students who learnt through a structured inquiry.

It is evident that teachers need a good understanding of the different aspects of inquiry in order to be able to vary the teaching and learning experiences acoording to their students' needs (Martin-Hansen, 2002).

IBL has been found to increase students' interest and motivation at all ages by giving students a leading role in the teaching and learning process. Several studies document the positive effect including long-term effect of IBL on student interest and attitude to science (Berg, Bergendahl, Lundberg \& Tibell, 2003; Gibson \& Chase, 2002). IBL activities created an environment that "fostered and nurtured that students' innate curiosity and questioning and the sharing of ideas" (Gibson \& Chase, 2002 p. 701). Students were more positive and put more effort into the work when assigned open versions of experiments rather than expository ones and asked more reflective questions (Berg et al., 2003).

The activities of a collaborative nature that are frequently involved may be one reason for the increase in interest. Cooperative learning has been found to increase students' interest in particular science topics (Day \&Bryce, 2013). The relation to real life situations, contexts and problems is another possible reason for the increase in interest.

\subsection{Implementation of IBL}

Implementation of IBL is no easy task for teachers. Firstly teachers need a clear understanding of what IBL entails. Many interpretations exist and Martin-Hansen (2002) points out that many teachers believe that the term applies to almost anything that they do and publishers cause further confusion when they promote all kinds of text-books by claiming that they are inquiry-oriented. Teachers' beliefs and attitudes may also hinder the adoption of IBL (Windschitl, 2002). It is not easy for teachers to change their classroom practices from teacher-centred instruction and use of structured inquiries to a studentcentred one in which they facilitate more open inquiry (Windschitl, 2002). Teaching through IBL requires confidence and skill on the part of the teacher. Teachers require content and procedural knowledge and understanding of the inquiry process (Shedletzky \&Zion, 2005). Inquiry actively involves students in the learning process, giving them autonomy however Mayer (2004) advises caution and guidance since: "when students have too much freedom, they may fail to come into contact with the to-be-learned material" (p. 17). The challenge for teachers "is to know how much and what kind of guidance to provide and to know how to specify the desired outcome of learning" (Mayer, 2004 p.17). All these demands, changes and expectations imply that changing classroom practice requires teachers to develop understanding, attitudes and skills hence the need for professional development (PD).

\subsection{Pofessional Development}

Eraut (1977) defines teacher development as: "The natural process of professional growth in which a teacher gradually acquires confidence, gains new perspectives, increases in 
knowledge, discovers new methods and takes on new roles" (p. 10), all of which are certainly required in the adoption of IBL.

Eraut believes that teacher development is influenced by three factors: the knowledge, experience and personality of the teacher; the school context; and professional contact and discussion outside the school. Any proposed educational improvement or reform needs to be accompanied by PD (Guskey, 2002) in order to encourage and support teachers with the change.

There are various types of PD programmes and courses but all aim to bring about improvement or change in understanding, attitudes, beliefs and practice and ultimately improved student learning. In fact a PD programme is often considered to be successful if it has an impact on classroom practice and learning outcomes (J oyce \&Showers, 1980). Guskey and Sparks (1991) believe that while essential for improved learning outcomes, PD alone may not be enough. Harland and Kinder (1997) propose a set of nine PD outcomes arranged in a hierarchy of three levels: provisionary; information; new awareness; motivation; affective; institutional; value congruence; knowledge and skills; and impact on practice.

PD programmes intended to help teachers change from traditional teaching to IBL must not only provide new awareness, newknowledge and experiences, and facilitate development but should also support anxieties, concerns and difficulties resulting from the proposed changes. Guskey (2002) recommends support, continued follow-up and pressure to ensure that teachers persevere with the implementation of the proposed change until positive feedback is available which is likely to re-inforce and encourage the new practice.

\section{Method}

\subsection{The context}

In 2007 Malta participated for the first time in TIMSS at Grade 8 and placed 30th out of the 49 participating countries in Science (Martin, Mullis \& Foy, 2008). While 21\% of Maltese students reached the Advanced and High Benchmarks, $52 \%$ of the students were at the Low (23\%) or below the Low international benchmark (29\%). These results are characteristic of education systems in which students experience frequent testing and high stakes examinations as main forms of assessment. According to the Assessment Reform Group (2002) testing motivates high achievers while lower achievers experience a lowering of selfesteem resulting in an increase in the gap between high- and low-achieving students.

Yearly national examinations as well as school based tests and examinations tend to dominate in secondary schools especially during the last two years of compulsory education which prepare students for the Secondary Education Certificate (SEC) Examinations. These examinations determine progression into post-secondary institutions. The examinationoriented school culture is accompanied by rather traditional classrooms with teacher-centred instruction in which the transmission mode is the predominant method of instruction (Borg, 2013; Gatt, 2011; Pace, 2000). 
The performance in TIMSS prompted authorities to look at the situation in Maltese science classrooms. Among the proposals is the adoption of IBL as a main method of instruction (MEEF, 2011).

Between 2010 and 2013, the author and colleagues from the Faculty of Education of the University of Malta participated in the FP7 project aimed at promoting IBL in Mathematics and Science classrooms across Europe, PRIMAS. This was one of a number of projects launched and supported by the European Union as part of its seventh framework programme to promote IBL following the publication of the Rocard report (Rocard et al., 2007). A main aim of the project was to provide long-term PD to teachers as a means of support during the introduction and implementation of IBL.

\subsection{The PD course}

Twenty-five teachers from five state schools who participated on a voluntary basis, were provided with PD for two years. Small groups of five teachers met every two weeks with a PD facilitator. The meetings took place during school hours within the school. The teachers were given a reduced teaching load to enable them to attend the PD sessions, prepare new lessons and resources, and reflect on their practice. During the meetings the teachers reflected on issues and practices related to IBL and to how inquiry may be encouraged and promoted; and worked on exercises and activities intended to help them reflect on their practice and on their students. These activities were part of PD modules developed for the PRIMAS project (PRIMAS, n.d.) and dealt with topics such as the use of questioning techniques to promote student thinking and helping students with collaborative learning among others. During the meetings tasks that teachers were required to try out in class were set with a deadline. There was also time for sharing experiences especially those related to their attempts at trying out IBL.

\subsection{Aims and research questions}

The study aimed to investigate Maltese teachers' experience of the introduction of IBL in their teaching, focusing mainly on the difficulties encountered, challenges faced and support needed as they attempted to move away from the traditional classroom to a more studentcentred one in the context of an examination-oriented school culture. The research questions addressed in this paper were:

- What were the challenges that teachers faced when introducing IBL in their teaching?

- What help and support do teachers need in the implementation of IBL?

\subsection{Participants}

The teachers who participated in the project did so on a voluntary basis. Five state secondary schools were selected and a meeting for teachers was held within each school in which they were informed about the project and invited to participate. The teachers who participated in the project were required to keep a reflective journal recording their experiences. 
Six of the participant teachers were interviewed. Sampling was purposeful (Patton, 1990): a teacher who taught a group of high achieving/ low achieving students; teachers from boys' and from girls' schools (state schools were single-sex schools at the time of the study); a teacher identified by a PD facilitator as one who had successfully taken up IBL.

Since the number of chemistry teachers who participated in this project was small, the study also includes other science teachers (integrated science, physics, chemistry, biology).

\subsection{Data collection}

The results reported in this paper were derived from journal and interview data. The two different sources of data provided a means of triangulation in an attempt "to seek convergence and corroboration through the use of different data sources and methods" (Bowen, 2009 p. 28) and as "cross-data validity checks" (Patton, 1990 p. 188). Measures to maximise reliability and validity were taken at every stage of the study.

The teachers participating in the project were required to record their experiences in a journal. For each entry, teachers were asked to give details of the subject taught, the topic, the date, teaching strategies used and IBL processes targeted. They were encouraged to include descriptions of experiences, their reflection and also actions required. J ournal entries were written throughout the duration of the PD course. Reflective journals were collected every term.

Semi-structured interviews with teachers were carried out in their respective schools. The selected teachers were invited to participate in the interviews intended to evaluate the PD course and to study their experience of implementing IBL. All teachers approached agreed to be interviewed. An interview guide with questions, probes and prompts was used. The guide consisted of a number of sections. One section asked for background information about the teachers such as the initial teacher education course they had followed and their teaching experience. Other sections were intended to determine teachers' beliefs and views about teaching and learning, about IBL and their experience of using IBL. Teachers were also specifically asked to give feedback about the PD sessions and the experience as a whole. Questions were read using the same sequence and the same words in each interview. Most questions were open-ended in order to allow respondents to raise issues that they felt were important.

The interviews were audio-recorded and transcribed soon after being carried out taking note of contexts and non-verbal information.

\subsection{Data analysis}

Data from both the journals and interviews were qualitative in nature. Analysis involved reading and making sense of the data. Data from both sources wereanalysed using Grounded Theory methods (Strauss \& Corbin, 1994). Interview transcripts and journal entries were read and re-read identifying major themes, categories and case examples (Bowen, 2009). Through different levels of analysis the data were coded using descriptive oodes as well as 
less specific and more general codes. The journals provided an account of the experience of implementing IBL as it happened together with teachers' reflections on the matter. In the interviews teachers spoke about their views as well as their experience. After completing the analysis of data it was evident that many themes were common across the different sources. The common themes integrated data gathered from different sources. The analysis procedure was repeated several weeks later to confirm the emerging themes.

\section{Results: Identification of challenges encountered and areas where support is required}

Challenges reported by the teachers fall under three categories. Some were teacher-related: a result of their beliefs and understanding or due to their new role in the inquiry classroom. Other challenges were a result of difficulties students were facing. Undercurrents of examinations and the influence of systemic challenges on classroom practice were also evident.

\subsection{Systemic challenges}

Lack of time, lengthy syllabi and high stakes examinations were three closely linked systemic challenges that were mentioned explicitly but were also behind many other difficulties encountered.

The most frequently mentioned issue was the time factor. All the teachers mentioned time constraints at some point or other. The most common concern was that these studentcentred activities were time-consuming and consequently teachers could not afford to use them except on rareoccasions. This is a direct result of the examination-centred environment where teachers are concerned about the voluminous syllabi that must be mastered by students in a relatively short period of time. In such situations teacher-directed transmission of knowledge is considered to be more time-efficient than student-centred approaches even though teachers can see the difference that teaching through IBL makes. In fact many positive statements, in which teachers appreciated the advantages and benefits of IBL, often ended with "however they take too long to do" or "but it is too time-consuming". For example one of the teachers wrote: "although it is beneficial to students' learning, one has to bear in mind that this is quite time consuming, therefore it is impossible to carry out such an exercise at a frequency which one would like." While another wrote: "Admittedly this method gives me more insight about the students' progress. I will try to repeat this exercise from time to time. The only problem is the time factor."

This illustrates one of the challenges faced when attempting to introduce IBL in such an examination-oriented culture. It also shows that changing curricula and curricular intentions are not enough unless accompanied by a change in assessment practices. It will be very difficult for IBL to thrive as long as these high stakes examinations and content-laden syllabi remain in existence and in power. 
The influence of examinations was also evident in a number of everyday decisions and choices made by teachers. The concern about time spent on inquiry activities was also a student concern. For example, a teacher reports that:

at the end of the lesson, students were frustrated by the fact that it took them a long time to finish their work when this method was adopted. Such students argued that it would have been better had I written the correct answer on the board for them to copy and study later at home.

Similarly the influence of examinations on students was also evident. Sometimes students, especially high achievers were so:

concerned with the final examination that they did not appreciate the beauty of trying things out ...they complained that we did not have enough time to work out examples similar to what they expected to find in their exam paper ... with the higher ability group I had the maximum attention when using equations to solve typical exam questions.

When this teacher carried out the same lesson with a group of low achievers, the lesson was highly successful, the students were motivated throughout, except when working out exam questions.

\subsection{Teacher-related challenges}

Teachers reported challenges related to their new role in class. From being the centre of all the activity in class they needed to learn how to behave in a new, less central position. Teachers also needed to encourage students to become active learners. For many teachers this meant looking at the kind of questions they asked in class and how they handled the ensuing discussion. For example one teacher reported how she resorted to the use of miniwhiteboards as a way of controlling students who called out answers without giving other students time to think. For some teachers the resulting enthusiasm and excitement on the part of the students was at times overwhelming. While managing overenthusiastic students was difficult, so was motivating those who usually sit passively and let the teacher and other students get on with it. Some teachers described students who would not make an effort when assigned work in groups and asked: "how do you motivate them?"

Occasionally, teachers struggled with class control since students did not know how to behave when working in groups: "I must say that the class was completely out of control! In fact I had different groups fighting about which activity they wanted to do ... there were some students who were fooling around ...."

Two very common difficulties encountered by the teachers in their first steps away from the traditional classroom were 'not telling the students' and knowing how and when to intervene as can be illustrated by these two comments:

There were moments when a few students got stuck and were about to loseinterest and start wasting time. So at that point I had to go to them and guide them to the notes. Maybe this is not proper IBL behaviour but it was necessary at the time. 
The students discussed and some of them argued about the statements using their prior knowledge ... I tried not to say a word and it was hard for me. Maybe I did give some clues. Next time, they will know that I can't help and hopefully they will not ask.

These quotations illustrate the dilemma that teachers were facing about the guidance and support that they should or should not give. They may also indicate insecurity as well as an unclear understanding of what IBL is. Although regularly participating in PD meetings many teachers initially believed that using IBL meant giving no guidance at all. This may have resulted in students being confused, teachers giving up and leading to the reluctance to implement IBL expressed by Kirschner et al. (2006). Finding the right level of challenge in activities was another part of teachers' experience of finding their way. Teachers reported instances when planned activities were too easy or too difficult for their students. There were also instances when students lacked the required background knowledge needed to complete the task:

... students were enthusiastic about it and started to discuss. However, they did not have enough knowledge to discuss in depth. I realised that this should have been donelater so that students would have enough conceptual knowledge for in depth thought.

Such reflective comments are evidence of teachers learning as they practice. However in an examination-oriented school context, teachers may feel that they cannot afford to experiment and make mistakes - there are important consequences at stake. This may lead teachers to give up and return to more familiar teaching techniques. For example a teacher wrote:

...it was not an easy task for the students, in fact none of the groups got it right...... When I realized that we cannot move on, I explained how it works in the traditional way and by means of a video.

Evidently this teacher gave up and went back to the traditional way. In such situations it is quite possible that a teacher decides never to try any other IBL activities again, and this is where support from colleagues is very important. In fact, having the PD meetings proved to be very helpful and the groups developed into communities of practice, learning together and supporting one another. As one of the teachers said:

... the fact that every fortnight we were able to meet and talk about our difficulties and discovering that we were experiencing similar problems, helped a lot ... working on your own you think that certain difficulties are only being experienced by you - and perhaps at that point you can't see a solution. When you discuss them with others, first of all you say: ah so it's not just me ... and from other people you may get an idea of how they are tackling a particular situation which you can learn...

In their reflective journals, teachers described the tasks and activities used in the chosen lessons. It is not easy or reasonable to judge or evaluate choice of task without knowing how it was used. A teacher may use a task that appears to be open and unstructured, in a way that stifles inquiry while another teacher may use a task that appears to be structured, in a way 
that encourages inquiry with students of a particular age or level. The data available in the journals show that the teachers involved in this study used a range of tasks and activities. In some instances the lessons and/or activities described appear rather teacher-centred while others were less so.

Practically all the tasks were closely related to the syllabus and at times even involved typical examination questions. The few exceptions of the use of tasks that were not strictly syllabus material all involved lower secondary classes. Teaching in the last three years of secondary school is all geared towards the SEC examination.

The choice of task may indicate several issues. It may illustrate the teacher's definition and understanding of IBL. For example it seems that for some teachers doing IBL involved frequent and almost continuous use of oral questioning. This may be an impression acquired since one of the first modules tackled during the PD course dealt with questioning that promoted reasoning. They may have simply equated questioning with IBL. For other teachers, inquiry meant a project-type of investigation that spanned over a number of lessons. While the inquiry potential of such a task is indisputable, teachers often accompanied accounts of such activities with concerns about the time spent and how they cannot afford to assign inquiry tasks more than once a year. This lack of understanding or misinterpretation of what IBL entails was also observed by Martin-Hansen (2002) who pointed out that "many educators ... misunderstand what is meant by inquiry, believing that the term applies to almost anything they do" (p. 34). In fact in this study there were instances when teachers were found to regard questioning, eliciting, any hands-on work and any teaching method as long as it was not lecturing as doing IBL. For some teachers, doing IBL involved students working completely on their own as in discovery learning.

Looking at journal entries written over a period of time there were several cases of improvement in choice and use of tasks. This could indicate an improved understanding of what IBL is or perhaps an increase in self-confidence in their ability to use IBL and in the students' ability to learn through inquiry. Teachers' understanding of IBL, in some cases, appeared to evolve from seeing IBL as anything as long as you are not 'telling the students' to giving students opportunities to think, discuss, formulate and communicate arguments based on evidence. These can be regarded as steps in the journey towards adoption of IBL.

It is evident that teachers needed time to develop their understanding of IBL as well as help and support to become more confident in the choice of tasks and in how tasks can be structured.

Difficulties related to scaffolding type and amount were also reported. A journal entry describes a lesson with a low achieving class in which the teacher asked specific questions and allowed students to try out their predictions and answers: "This helped them think and then verify and if necessary rectify their ideas. They appreciated the fact that the lesson was hands-on ...". When the teacher attempted to do something similar with a high achieving class, the students did not cooperate and felt that it was a waste of time. This may indicate 
that students did not find the task challenging enough. Clearly, providing the right scaffolding and level of challenge is not always easy.

Both teachers and students seemed to be greatly concerned about oorrect and incorrect answers. Teachers often commented about student performance in terms of right and wrong answers. Providing feedback about correct and incorrect answers also appears to be one of the main forms of classroom interaction. Many teachers described their efforts as well as difficulties experienced when trying to beless judgemental during a class discussion or other activity. This concern is illustrated in Table 1.

\subsection{Student-related challenges}

Teachers reported a number of challenges that students were experiencing as a result of the change taking place. These are summarized in Table 1.

Table 1: Student-related challenges

\section{Challenge Description/illustration}

\begin{tabular}{|c|c|}
\hline $\begin{array}{l}\text { All students } \\
\text { encouraged to be } \\
\text { active learners }\end{array}$ & $\begin{array}{l}\text { Students who were quick thinkers and were used to getting instantaneous reward for their } \\
\text { answers during whole class teaching found it difficult to think and wait, give other } \\
\text { students time to think or let other students have a go. }\end{array}$ \\
\hline $\begin{array}{l}\text { From being } \\
\text { totally teacher- } \\
\text { dependent to } \\
\text { becoming } \\
\text { autonomous } \\
\text { learners }\end{array}$ & $\begin{array}{l}\text { Students who were very, if not totally, teacher-dependent found it difficult to work on } \\
\text { tasks without the teacher's constant feedback, as two teachers noted: } \\
\text { "students were watching my body language while I was giving comments and they tried } \\
\text { to guess whether the answer was correct or not". } \\
\text { "some students were completely at a loss and could not concentrate without my } \\
\text { presence... some asked me to stay around in order to check whether they were on the } \\
\text { right track". }\end{array}$ \\
\hline $\begin{array}{l}\text { From } \\
\text { considering } \\
\text { learning as an } \\
\text { individual } \\
\text { activity to } \\
\text { learning } \\
\text { collaboratively }\end{array}$ & $\begin{array}{l}\text { Some students were unable to work in a group, let alone as a group. A teacher gives the } \\
\text { following description in her first journal entry: "I noticed that within the groups there } \\
\text { were some who were completely lost and weren't even writing down results ... or trying } \\
\text { to make sense of the results obtained... I now realise that the students are not familiar } \\
\text { with working in groups... I have expected too much of my students, seeing that this was } \\
\text { their first experience..." }\end{array}$ \\
\hline $\begin{array}{l}\text { From } \\
\text { competitive to } \\
\text { cooperative }\end{array}$ & $\begin{array}{l}\text { Some students were very competitive. This was often utilised by teachers to motivate } \\
\text { students especially boys. For example one teacher used: "a quiz and points system.... } \\
\text { Students were motivated to work and to compete with each other." Another teacher } \\
\text { displayed homework marks on the board: "I find that it keeps them on their toes, makes } \\
\text { them work harder. I try to use it with certain classes ... it seems to work: I show their } \\
\text { marks on the interactive white board ... it is a very good class and they compete'. It is no } \\
\text { surprise that students did not feel comfortable to think, suggest, and collaborate if their } \\
\text { marks were regularly exhibited on the board. }\end{array}$ \\
\hline
\end{tabular}

\begin{tabular}{|c|c|}
\hline $\begin{array}{l}\text { From emphasis } \\
\text { on correct } \\
\text { answers and } \\
\text { avoiding } \\
\text { mistakes to } \\
\text { learning from } \\
\text { mistakes }\end{array}$ & $\begin{array}{l}\text { Students were unfamiliar with the possibility of having more than one correct answer or } \\
\text { writing an incorrect answer and learning from mistakes. Some students were so used to } \\
\text { having teachers' immediate feedback about what is correct or incorrect that they were } \\
\text { frustrated and unable to progress when their teacher refused to comment about a } \\
\text { suggestion or answer. For example, when asked to think, discuss and write down all ideas } \\
\text { even if they were not sure whether they were correct, a group of students: "were } \\
\text { apprehensive of giving an incorrect answer" and attempted to find one correct answer. As } \\
\text { their teacher reflected: "students need to be encouraged to express all their ideas and not } \\
\text { be afraid of not being correct or precise. More frequent exercises of this type are needed } \\
\text { to show them that it is the process of thinking that is important and in reality the outcome } \\
\text { is not always predictable". }\end{array}$ \\
\hline
\end{tabular}


Students were experiencing difficulties due to the changes in classroom environment and activities and these initial difficulties at times led them to resist the changes. Teachers are likely to be discouraged when they come across this resistance.

\subsection{Feelings reported}

A number of feelings and emotions were reported in the journals and the interviews which clarified further the picture of the traditional classroom trying to embrace IBL.

Teachers used to dishing out information to their students, often reported surprise, amazement and disbelief at what their students managed to achieve and wrote comments such as: 'I was surprised at how much they already knew'. This appears to be unexpected to the teacher who usually employed a teacher-centred approach that involved 'telling', students resulting in teacher-dependent students.

Enjoyment was frequently reported: "it was very interesting to hear them argue and discuss ...", as was satisfaction at the end of a successful task: "I was very pleased with the outcome and I am sure the students understood better. I will surely carry out this activity again". Positive experiences, expected or unexpected, are likely to encourage teachers to carry on and advance their use of IBL. Guskey (2002) in fact proposes that the experience of successful implementation, changes teachers' attitudes and beliefs and results in a change in teachers' practice.

Other feelings were less positive and in the beginning fear, and lack of self-confidence were often evident in the comments:

for me the biggest challenge was the beginning. What am I going to do? How am I going to do this? I've never done anything like it. What if they ask me something that I can't answer there and then, what am I going to do?

Such teachers were hesitant and not very adventurous in their attempts. In fact in some of these cases, teachers reported giving up on a type of activity that did not work and often limited their use of IBL to rare occasions. It is clear that teachers need the support of colleagues, administrators and mentors to encourage and reassure them. On the other hand teachers who were more self-confident were ready to try other things:

Since group work worked well, I plan to increase activities involving group work ... being more confident throughout the activity helped me make use of a variety of inquiry-based questioning techniques. This encourages me to include more IBL processes in my lessons.

By sharing experiences in a community of practice, teachers inspire and support each other.

\section{Discussion and implications}

\subsection{Professional Development}

It is evident that the PD sessions were instrumental in encouraging teachers to start considering IBL and supporting them in their attempts. Many lessons described wereinitially 
still rather teacher-centred and teacher-driven but the participants appeared to be trying to let go traditional teaching by including activities that were less teacher-centred.

Teachers needed time to develop their understanding of what IBL entails. Several inaccurate interpretations of IBL were observed. For some teachers any improvement to their lessons such as assigning hands-on work or using class-questioning meant that they were doing IBL. PD sessions should provide the time and opportunity for these views to be aired so that they can be addressed. Some of these views were evident in the journal entries and confirmed through observations carried out (for research purposes) in another part of the study that is not reported in this paper. The methodology adopted in the PD course did not involve observation of the participating teachers' lessons as part of the course. This may have resulted in a gap between what teachers said during the PD sessions and what they actually did in practice. Including lesson observations, possibly teachers observing one another's lessons and discussing lessons with a 'critical friend' would address this limitation.

It is not easy for teachers to change their role to a less central one, supporting and scaffolding student learning. The long-term PD course spread over two years helped the teachers learn about IBL and how it can be used. It also encouraged teachers to try using this pedagogy in class through tasks that teachers were expected to try out by the following PD session. Time, practice and support are required to help the teacher let go the traditional role. Peer support within the school is very important. A teacher who has no peer support may give up due to isolation especially when faced with systemic challenges and barriers.

PD courses need to help teachers learn how to behave in their new role; how to deal with overenthusiastic students; how to motivate passive students to become active learners; how to find the right level of challenge; and how to decide when IBL is the appropriate pedagogy and when it is less appropriate. The PD meeting and the community of practice can be very helpful in this respect.

The changes teachers are expected to undertake cannot be achieved through one-off courses. Teachers need help and support as they develop the confidence to deal with issues and difficulties involved.

\subsection{Students}

It is challenging for the students to get used to the new classroom environment and to IBL challenges. Students who have always considered learning as an individual activity are now required to learn collaboratively. Students who are accustomed to a competitive environment with selective examinations, marks and prizes must adjust to learning in a cooperative environment. Inquiry also results in a change in emphasis: from emphasis on correct answers and not making mistakes, to emphasis on the process and learning from mistakes. And perhaps the hardest of all is the change from being totally teacher-dependent to becoming more autonomous.

Initially students may resist the changes due to the difficulties caused by these expectations. This is particularly evident when inquiry is first introduced with older students, 298 
especially high achievers. Such students have had a longer experience and enculturation in the traditional classroom. The traditional system with teacher delivering, students revising and reproducing what they learn on the examination paper was fine for high achieving students. They performed well and were rewarded with success, so why change and risk losing all this? Any divergence from that model is a waste of time. Experiencing IBL very early in their science lessons, preferably right from primary school, will give students time to learn and assimilate inquiry skills over several years of schooling. Also, students should not be assessed only on knowledge and understanding but also on other skills. In this way, students would value other skills and the process of inquiry as much as knowledge acquisition.

\subsection{Curricula and Assessment policies}

Lack of time, long syllabi together with high stakes examinations that test acquisition of knowledge appear to be a major barrier to wider use of IBL. Faced with long syllabi that need to be covered and high stakes examinations that are used as the yardstick to measure their effectiveness and their students' success, teachers may abandon IBL and other studentcentred approaches. Transmission of knowledge is more time-efficient giving teachers control over how much is covered per lesson. High stakes examinations result in frequent testing and in learning for the test, and student-centred pedagogies such as IBL are seen as a waste of time or at best as taking precious time that can be spent otherwise. If science syllabi retain the amount of material that students are expected to learn and if examinations maintain their present importance and content, the good intentions expressed in policy documents (MEEF, 2011; MEE, 2012) will fail to be as successful as they could be. Including the assessment of skills and competences that are relevant to current needs is more likely to encourage the adoption of inquiry and other student-centred pedagogies. It is evident that curricula and assessment policies need to be aligned.

\section{Conclusion}

The difficulties enoountered have two important implications. First the need for curricula and assessment policies to be aligned. Secondly the need of long term PD that promotes active involvement of participants and which provides long-term support. Ideally, there should be on-site support with teachers working as a school team and developing a community of practice in which teachers reflect, observe one another's lessons and discuss the lessons with a critical friend. This is needed to reduce the barriers and support teachers as they implement strategies that help students acquire an interesting and meaningful science education. Teachers need help to develop their understanding of IBL. They need support as they experiment and develop in their new role as teachers in an IBL environment rather than teachers in a traditional classroom environment. Long-term PD and support will increase the likelihood of a long-term change in practice that goes beyond the duration of the PD course. 
FARRUGIA

\section{Acknowledgement}

The project PRIMAS has received funding from the European Union Seventh Framework Programme (FP7/ 2007-2013) under grant agreement $n^{\circ} 244380$. 


\section{References}

Annetta, L.A., Cheng, M.T. \&Holmes, S. (2010) Assessing twenty-first century skills through a teacher created video game for high school biology students Research in Science \& Technological Education, 28 (2) 101- 114.

Assessment Reform Group (2002) Testing, Motivation and Learning. Cambridge, University of Cambridge Faculty of Education.

Bell,T., Urhahne, D., Schanze, S. \& Ploetzner, R. (2010) Collaborative inquiry learning: Models, tools, and challenges International J ournal of Science Education 32(3) 349- 377.

Berg, C. A. R., Bergendahl, V. C. B., Lundberg, B., \&Tibell, L. (2003). Benefiting from an open ended experiment? A comparison of attitudes to, and outcomes of, an expository versus an open-inquiry version of the same experiment. International J ournal of Science Education, 25(3), 351- 372.

Borg, A. (2013). Physics Students' Perceptions on Teacher Pedagogies. Unpublished Bachelor's dissertation. University of Malta: Malta.

Bowen, G.A. (2009). Document analysis as a qualitative research method. Qualitative Research J ournal, 9 (2), $27-40$.

Bunterm,T., Lee, K., Ng Lan Kong, J ., Srikoon, S., Vangpoomyai, P., Rattanavongsa, J . \& Rachahoon, G. (2014). Do different levels of inquiry lead to different learning outcomes? A comparison between guided and structured inquiry. International J ournal of Science Education, 36 (12) 1937-1959.

Business Higher Education Forum (2005). A commitment to America's future: Responding to the crisis in mathematics and science education retrieved from: http:// www.brockport.edu/iccse/ documents/ MathEduReport-press.pdf

Cobern, W.W., Schuster, D., Adams, B., Applegate,B., Skjold, B., Undreiu, A., ... D. Gobert, J.D. (2010). Experimental comparison of inquiry and direct instruction in science. Research in Science \& Technological Education, 28 (1), 81-96.

Day, S.P. \&Bryce, T.G.K. (2013). The benefits of cooperative learning to socio-scientific discussion in secondary school science. International J ournal of Science Education, 35(9), 1533-1560.

Eraut, M. (1977). Strategies for promoting teacher development. British J ournal of In-Service Education, 4(1-2), 10-12.

Eurobarometer (2005). Europeans, Science and Technology. Retrieved from: http:// ec.europa.eu/public_opinion/archives/ ebs/ ebs_224_report_en.pdf

European Commission (2007). Key Competences for Lifelong Learning. European Reference Framework. Luxembourg: Office for Official Publications of the European Communities.

Fradd, S. H., Lee, O., Sutman, F. \& Saxton, K. (2001). Promoting science literacy with English language learning through instructional materials development: A case study. Bilingual Research J ournal, 25 (4), 417- 439.

Gatt, C. (2011). Integrated Science in Secondary Schools: Teachers' Perspectives and Views. Unpublished Bachelor's dissertation. University of Malta: Malta.

Gibson, H.L. \&Chase, C. (2002). Longitudinal impact of an inquiry-based science program on middle school students' attitudes toward science. Science Education, 86(5), 693-705.

Guskey, T.R. \& Sparks, D. (1991, November). What to consider when evaluating staff development. Educational Leadership, 73-76.

Guskey, T.R. (2002). Professional development and teacher change. Teachers and Teaching: Theory and Practice, 8(3) 381-391.

Harland, J . \& Kinder, K. (1997). Teachers' continuing professional development: framing a model of outcomes. British J ournal of In-Service Education, 23(1), 71-84.

Harwell, S.J . (2003). Teacher Professional Development: It's Not an Event, It's a Process. Waco, TX: CORD Communications, Inc. 
Hmelo-Silver, C.E., Duncan, R.G. \&Chinn, C.A. (2007). Scaffolding and achievement in problembased and inquiry learning: A response to Kirschner, Sweller, and Clark (2006) Educational Psychologist, 42(2), 99-107.

J oyce, B. \& Showers, B. (1980, February). Improving inservice training: The messages of research. Educational Leadership, 379-385.

Kirschner, P. A., Sweller, J ., \& Clark, R. E. (2006). Why minimal guidance during instruction does not work: An analysis of the failure of constructivist, discovery, problem-based, experiential, and inquiry-based teaching. Educational Psychologist, 41, 75- 86.

Krapp, A. \& Prenzel, M. (2011). Research on interest in science: theories, methods, and findings. International J ournal of Science Education, 33 (1) 27-50.

Linn, M. C., Davis, E. A., \& Bell. P. (2004). Inquiry and technology. In M.C. Lin, E.A. Davis, \& P. Bel (Eds.), Internet Environments for Science Education (3-28). Mahwah, NJ: Lawrence Erlbaum Associates.

Logan, M.R. \& Skamp, K.R. (2013). The impact of teachers and their science teaching on students' 'science interest': A four-year study. International J ournal of Science Education 35 (17) 28792904.

Maaß, K. \& Euler, M. (2011). PRIMAS WP9 - Report about the survey on inquiry-based learning and teaching in the European partner countries. EU-Project PRIMAS, Deliverable $N^{\circ}$ 9.2.

Martin, M.O., Mullis, I.V.S., \&Foy, P. (2008). TIMSS 2007 International Science Report: Findings from IEA's Trends in International Mathematics and Science Study at the Fourth and Eighth Grades. Chestnut Hill, MA: Boston College.

Martin-Hansen, L. (2002, February). Defining inquiry: Exploring the many types of inquiry in the Science classroom. The Science Teacher, 34-37.

Mayer, R.E. (2004). Should there be a three-strikes rule against pure discovery learning? The case for guided methods of instruction. American Psychologist 59(1), 14-19.

Ministry of Education, Employment and the Family (MEEF) (2011). Vision for Science Education, Consultation document. Malta: Government of Malta.

Ministry of Education and Employment (MEE) (2012). A National Curriculum Framework for all. Malta: Salesian Press.

National Research Council (1996). National Science Education Standards. Washington DC: National Academy Press.

OECD (2006). Evolution of Student Interest in Science and Technology Studies - Policy Report. Global Science Forum.

OFSTED (2013). Maintaining curiosity: A survey into Science Education in schools No. 130135.

Olson, S. \& Loucks-Horsley, S., (2000). Inquiry and the National Science Education Standards: A Guide for Teaching and Learning. Washington, D.C: National Academy Press.

Osborne, J . \&Collins, S. (2001) Pupils' views of the role and value of the science curriculum: A focusgroup study, International J ournal of Science Education, 23 (5) 441-467.

Pace, P. (2000). The State of Science Education in Malta. The Malta Council for Science \& Technology, Malta.

Patton, M.Q. (1990). Qualitative Evaluation and Research Methods ( $2^{\text {nd }}$ ed), Newbury Park, CA: Sage.

PRIMAS (n.d.). Professional development modules for inquiry-based, collaborative learning. retrieved from http:/ / www.primas-project.eu/ artikel/ en/ 1221/ professional-developmentmodules/view.do

Rocard, M., Csermely, P., J orde, D., Lenzen, D., Walberg-Henriksson, H. \&Hemme, V. (2007). Science Education now: A renewed Pedagogy for the Future of Europe, Brussels: European Commission. 
Sesen, B.A. \& Tarhan, L. (2011). Active-learning versus teacher centered instruction for learning acids and bases, Research in Science \& Technological Education, 29 (2) 205-226.

Shedletzky, E. \&Zion, M. (2005). The Essence of Open-Inquiry Teaching. Science Education International 16(1), 23-38.

Strauss, A. \& Corbin, J . (1994). Grounded theory methodology - An overview. In N. K. Denzin and Y. S. Lincoln (Eds.) Handbook of Qualitative Research, (pp. 273-285). Thousand Oaks, CA: Sage.

Tafoya E., Sunal, D., \& Knecht, P. (1980). Assessing inquiry potential: a tool for curriculum decision makers. School Science and Mathematics, 80, 43-48.

Windschitl, M. (2002). Inquiry projects in science teacher education: What can investigative experiences reveal about teacher thinking and eventual classroom practice? Science Teacher Education 87, 112-143. 